\title{
Price Reduction in Vienna Sales Convention and Compatibility Check in Sale of Goods Act of Pakistan
}

\author{
SYED MUDASSER FIDA GARDAZI \\ Assistant Professor of Law, University of Azad Jammu and Kashmir, PO 13100, Pakistan. \\ PhD Law Scholar at IIUI, \\ Email: smgardazi@gmail.com / smgardazi@ajku.edu.pk \\ Tel: +923335551040
}

Dr. MUHAMMAD ASIM IQBAL

Assistant Professor of Law, International Islamic University Islamabad.

Email: drmaiqbal@live.com

Tel: +923335922228

HAFIZ MUHAMMAD USMAN NAWAZ

Assistant Professor of Law, International Islamic University Islamabad.

Email: usman.nawaz@iiu.edu.pk

Tel: +923338147181

\begin{abstract}
Price reduction is one of the civil law remedies incorporated in the Vienna sales convention. On the other hand, Pakistan is neither the signatory of the convention nor its national sales law posses this remedy. Therefore a research is highly required to fill this vacuum and find out a solution for international buyer who is involved in trade with parties in Pakistan. Thus the study aims to investigate the suitability of price reduction in compatibility with existing legal regime. The study reveals the raison d'être in contract making via relative analysis of the existence of price reduction as an assurance for performance and certainty. The results depict that adding price reduction as remedy will be a good legal cover to the buyer's claims and a better response to the business practices in Pakistan. Especially, where the buyer is facing difficulties to prove his loss he may simply opt to reduce the price. Hence, study recommends that introducing the 'price reduction' as a remedy in the local legal system will enhance the confidence of a commercial buyer from the international community.
\end{abstract}

Keywords: Sale of Goods, CISG, Price Reduction, Remedy.

\section{Introduction}

The remedy of the price reduction deals with the monetary form of compensation against a breach of contract and study reflects the remedial aspects for a commercial buyer. Moreover, it is a comparative analysis of the two legal regimes that is Sale of Goods Act, 1930 of Pakistan (SOGA) and United Nations Convention on Contracts for the International Sale of Goods, 1980 (CISG or Vienna Sales Convention). Price reduction is not a clear part in SOGA (Raza, 2019 and Malik \& Ahmed, 2018) while the CISG provides remedy of price reduction for a commercial buyer of manufactured goods (Demirel, 2019 and Schwenzer, 2017). The price reduction in CISG seems more important than other remedies like the damages as it emphasis on the performance and certainty in a contract for sale of goods. 
The main objective of the study is to explore the viability of price reduction as remedy in comparison with its impact of non existence to concluding a contract for international sale of goods. Moreover, it has to find the suitability of 'price reduction' in existing legal structure of Pakistan.

The basic question responded here is; whether the price reduction enhances the commercial utility as an assurance for performance and certainty?

The method of the study is qualitative mainly based upon the analysis of literature about raison d'être (rationality) in contract making. The description and evaluation of the concept of price reduction as remedy provided by CISG is also presented. Alongside, it is a comparative analysis of the coexistence of price reduction with other remedies in the SOGA by observing its possible occurrence in the courts' practices and business in the country.

The study is further supported with the discussion on few other remedies, applicable in sale of goods but provided in the Contract Act, 1872 (CA), resembling the remedy of price reduction. For example, novation, remission and rescission of agreement on failure of part performance are found as the key alternative remedies (Section 62 and 63 of CA). The main reason to discuss the remedies provided by the CA here is the presence of section 3 of the Sale of Goods Act, 1930 which explains the principle of application of these alternative remedies in sale of goods contracts.

Section 3 says:

"The un-repealed provisions of the Contract Act, 1872, save in so far as they are inconsistent with the express provisions of this Act, shall continue to apply to contracts for the sale of goods."

At the end of the study, the rationale for contract making to measure the value of price reduction is assessed and the equitable suggestions are proposed to harmonize the relations between the two regimes of law.

\section{CISG on Price Reduction}

Since the times immemorial, the price reduction, in general terms, has always been a negotiable mechanism from buyer s point of view to establish a bargain with sellers. Not an even idea but perhaps still the concept prevails to satisfy the desire of a commercial buyer and this term became a remedy in case of breach of contract occurs, specifically when conformity of goods is in question. Conformity of goods is related to their delivery upon completion of a contract (Lazerow, 2019 and Jansen, 2013).

The remedy of price reduction (Article 50, CISG) was evolved initially in continental Europe and specifically was based upon the concept "actio quanti minoris"1 of Roman law (Cornelius, 2013). As the price reduction revolves around the conformity of goods and Article 35(1) of the CISG talks on the subject as "the seller must deliver the goods which are of the quantity, quality and description..." Moreover, it focuses on the prescribed terms of contract even for its manner (Article 35, CISG). Schwenzer guides us that nonconformity of goods brings various remedies in general like specific performance, avoidance of the contract, damages and price reduction and all of them are connected by nonphysical features of the goods (Schwenzer, 2012).

${ }^{1}$ Actio quanti minoris originally a remedy in Roman law granted to the aedile (a magistrate with jurisdiction over markets) when a latent defect appeared that had not been revealed to the buyer, allowing the buyer (within a year) to seek the difference between the price paid and the value. Liability was strict. In late Roman law it applied even to land. It is still discussed in civilian jurisdictions to this day. (Dictionary of Law, Second Edition, W.J. Stewart, at 10) 


\section{Price Reduction: A Right or Myth}

Article 79 of the convention talks about the exemptions from liabilities of the parties due to the pediments unavoidably imposed thereupon (Magnus, 2010 and Flechtner, 2007). However, the right to price reduction is still available to the buyer for the non-conformity of goods which may constitute either a fundamental or a simple breach of contract. Moreover, Article 50 is not in conjunction with Article 77 of the CISG, which drags the buyer to tone down his losses aligned with his pending duty; therefore, the buyer can seek price reduction in such circumstances as well (Han, 2016). It is not well agreed among the scholars that the buyer should be provided space for his failure to mitigate losses. One argument is supplementing the above statement given by a commentator on CISG that the buyer's right to price reduction is not related to his duty to mitigate losses provided in Article 77 (Butler, 2017).

The other point of view is that Article 77 is applied to a wide range of remedies and Article 50 brings also the concept of mitigation (Honnold, 2009). The theme of previous argument instead of latter sounds better as the objective of the price reduction is to preserve the bargain or the principal contract through a renovation rather the compensation only. Here, the buyer retains the goods even so non-confirming by adjusting the price on lesser value that previously agreed between the parties (Gonzalez, 1984). Consequently, the rules such as 'duty to mitigate' or 'the test of foresee-ability' possibly will not be applied whenever providing the remedy of price reduction (Beheshti, 2016). Parallel to this, it is argued that the scope of price reduction is limited. It only applies to the breaches related to non-conformity of goods for the defects in quantity or quality. In other words, it applies for 'delivery of non-conforming goods and also for an aliud [totally changed goods] (Huber, 2007 and Bergsten, 1979). Therefore, it is of no use in other breaches i.e. non-delivery or late delivery of goods. Furthermore, the seller cannot be asked for price reduction if he entertained the same cause of action with a remedy described either in Article 37 or 48 of the CISG like early and late delivery of goods respectively (Agapiou, 2015). The buyer however is duty bound to notifying defect to the seller which may become an impediment as well in availing the remedy of price reduction (Agapiou, 2015). It is a matter of general principles of equity, the vigilant not the indolent can seek remedy, various actions and abstentions might disqualify the buyer for his right to declare price reduction. Foregoing in view, a buyer must inform the seller through a notice of the nonconformity before declaring a price reduction. In case of his failure to do so he may face a result in abstention from his right to reduce price. However, the buyer also has shields to protect his application of price reduction available through Article 40 and 44 of the CISG (Sanne, 2013 and Anselmo, 2005). Article 40 in case of the seller's knowledge of defect, or presumed to be in his knowledge, without taking a plea of buyer's chance to examine the goods and sending notification protects the buyer. Besides, Article 44 exempts the buyer from his duty to notify the defective goods by raising a reasonable excuse for not making such a notice.

\section{The Quality of Price Reduction}

Price reduction, in all other remedies provided by the CISG, is one of the readily available remedies because non-conformity within delivered goods, without more, entitles the buyer to declare a price reduction (Fountoulakis, 2011). It is a unilateral right for the buyer to declare a reduce price of purchase. So, he can alter the terms of the contract unilaterally. Comparing with other remedies, the buyer doesn't require applying in court for exercising this right which brings him a saviour from lengthy procedures (Piche, 2002). The important requisite for the buyer is to declare a reduction of the purchase price timely if he wants to apply for this remedy. The declaration must be cleared in terms of reducing price of the purchase however, the words 'price reduction' are not necessary to use (Shin, 2005).

Besides, it is also a debate whether price reduction is claim or a defence (Kalamees \& Sein, 2015). The remedy is more or less to preserve the bargain and it is possible even after receiving non-confirming goods but at the option of receiving end or the buyer. According to the language and its widely acknowledged interpretations, Article 50 of the CISG allows the buyer to alter the terms of contract unilaterally without any approval from the seller. So it cannot be rated as defence rather it suits as a claim. 


\section{Purpose of Price Reduction}

The buyer can bring an action for reduction of price or for rescission of contract if he sees any specified defects in goods, after delivery, which the seller did not declare at the time of contract and which if buyer new then he might reduce the price (Sanne, 2013).

Here, the buyer pays the price in lower amount then actual one agreed and keeps the defective goods after the disclosure of the fact as he would have been purchasing with knowledge of defects in earlier stages of making the principal contract. The worth of remedy is calculated here upon the basis of an estimated cost extracted from an imaginary relationship between the actual value of goods delivered and the presumed value of conforming goods. This would be a 'proportionate' calculation. We do have the formula (Catherine, 2002) to calculate this value as provided by the existing scholarly work and interpretations by courts:

$$
\text { Reduced Price }=\frac{\text { Value of the Goods Delivered } \times \text { Contract Price }}{\text { Hypothetical Value of Conforming Goods }}
$$

\section{SOGA and the Price Reduction}

Price reduction is not present in SOGA as an independent remedy. However, it is debatable whether it is totally missing or partly present. It is a matter of fact that SOGA is a common law device so it lacks the principle of price reduction for non-conforming goods (Zeller \& Ali, 2017). Legal practitioners in Pakistan are not clear in their approach to price reduction as an independent remedy rather they focus on the right to claim damages. The damages being only remedy is a quite common cause to not think out of box in Pakistan while in civil law systems there are possibilities to have price reduction as alternative and comparatively easier then claiming damages, which requires the breach of contract from seller and his fault.

Section 59 of SOGA deals with remedy against breach of warranty and Section 37 is dealing with the 'delivery of wrong quantity' of goods. Section 16 of SOGA discusses the 'implied conditions as to quality of fitness'. Moreover, section 16-A of SOGA compels the seller with the title "seller to inform buyer of defect in goods sold" for his liability to disclose defects in goods. It may be argued that these provisions of law entail the foundation of price reduction and claim to damages both being their resembling nature for similar causes of action in a breach of contract. This argument, however, is not successfully addressing the need of price reduction. The provision of set-off, in section 59, does not operate directly without a breach of warranty. Contrary to the 'price reduction' the remedy of set-off can be calculated in proportion to the loss suffered by the buyer (Hassan, 2019). Price reduction, in its own way, depends upon the deadpan difference between the delivered and conforming goods.

Principally, the scope of section 37 of SOGA is limited to delivery of wrong quantity while article 50 of CISG has a wider application (Sanne, 2013). Section 37 (1) says:

"Where the seller delivers to the buyer a quantity of goods less than he contracted to sell, the buyer may reject them, but if the buyer accepts the goods so delivered he shall pay for them at the contract rate."

Meaning thereby is that the price would be reduced for the buyer to the portion of undelivered quantity of goods on the agreed rate as per contract (P L D 1958 Dacca 512, and 2012 CLD 276 (b) Sindh). CISG gives the similar estimation vide Article 50. So the remedy on less delivery of goods under Section 37 of SOGA may be treated as price reduction enshrined in Article 50 of CISG.

Few other remedies resembling with price reduction are provided by the CA. Section 62 of the CA (effect of novation, rescission and alteration of contract), provides for some of these remedies as: 
"If the parties to a contract agree to substitute a new contract for it, or to rescind or alter it, the original contract need not be performed."

The point to remember here is that these remedies ${ }^{2}$ are available by way of mutual agreement between the parties. Parties may change terms and conditions of their agreement subsequently by way of another mutual agreement. There are different modes of discharge of contracts. Generally, one party cannot discharge the contract with his unilateral action without the consent of other party. If it is, it will be considered as breach of contract. But if the contract is discharges by the mutual agreement of the parties, there will be no breach of contract. Section 62 provides for three modes of discharge of contract. First is the novation. The Term novation has been defined by the House of Lords (Scarf v Jardine, (1882) 7 AC 345) in these words:

"There being a contract in existence, some new contract is substituted for it either between the same parties (for that might be) or between different parties, the consideration mutually being the discharge for the old contract."

In United Bank Limited versus M/S Aziz Tanneries (Pvt.) Ltd., it was held by a learned Single Judge of the Lahore High Court that novation of contract takes place when for an existing contract some new contract is substituted either by the same parties or between different parties, consideration mutually being the discharge of old contract; when the contract is novated, a fresh contract comes into existence directly or by implication in place of the original contract; and, the effect of novation is that it extinguishes the original contract and replaces it by another (2004 CLD 1715 Lah.).

Original contracts stands wiped out and needs not be performed. No claim for that may be in the court of law against either party to contract. Similarly, alteration in the original contract is enough to prove that the contract has been substituted and the original contract needs not to be performed, it has the effect of rescission of contract by mutual agreement. If the original contract is altered in such a way that it creates only some modifications in the terms of the contract but not the substantial change or substitution, then it will not be treated as rescission of the original contract by mutual agreement (1981 CLC 638 Kar.).

Section 63 (promisee may dispense with or remit performance of promise) of CA draws the attention towards another mode of discharge of contract that is remission.

"Every promisee may dispense with or remit, wholly or in part, the performance of the promise made to him, or may extend the time for such performance1, or may accept instead of it any satisfaction which he thinks fit."

In this situation, promisee can dispense the promisor not only without consideration but without a new agreement. Once the performance is dispensed by the promisee, he cannot retract from it (PLD 1975 SC 193).

Another mode of discharge of contract is provided by the Section 56 of the CA (contract to do act afterwards becoming impossible or unlawful), in the form of force majeure or frustration of contract. Section 56 paragraph 2 says:

"A contract to do an act which, after the contract is made, becomes impossible, or, by reason of some event which the promisor could not prevent, unlawful, becomes void when the act becomes impossible or unlawful."

\footnotetext{
${ }^{2}$ Strictly these are not remedies. These are the ways to discharge the contract by mutual agreement without creating any claim of damages for breach of original contract by either party on one another.
} 
When the performance of the contract becomes impossible or illegal without any fault of either party to contract, parties are discharged from their respective obligations. There will be no claim of damages against the party that has not performed the contract due to that impossible event.

The whole discussion in the context of Sections 56, 62 and 63 is relevant with the discussion of price reduction as remedy in sales law. These sections provide modes where parties may discharge their respective obligations in the contracts including the contract of sale of goods without creating any right to claim damages for nonperformance. These rights may be exercised without a claim of damages. Therefore where price reduction is claimed as a remedy to avoid the claim of damages, these modes may also be adopted.

\section{Analysis and Distinctions among Remedies}

Price reduction is a mere some of the hypothetical and actual values of the confirming goods respectively. On the other hand, in set-off, the price is reduced on the basis of the difference between the market price and the actual value of the goods (Piliounis, 2000). The price reduction, alternatively, is a relation between the hypothetical value of the confirming goods and the actual value of the goods delivered. Buyer seeking price reduction has to notify the nonconformity of goods to the seller and declare the price reduction upon which the seller is liable to respond accordingly (Article 39, 37 and 48 of CISG). An efficient seller can rectify his commodities before such notifications and declaration to avoid an initiation of procedure of price reduction by the buyer (Arts 48 and 50).

The "reliability" test depends upon preservation of interests being a buyer. Hence, if the buyer observes that price reduction is certain, it protects the interest of performance of contract, it is efficient (Friedmann, 1995 and Weinrib, 2003). By "sustainability", this study intends to elaborate the preservation of contract in a way to continue business relation between the parties instead of blocking the furtherance of commercial transactions.

Claiming a price reduction by a buyer cannot be added simultaneously for delivery of goods or their repair (Šobot, 2017). Since, these two remedies are not a combination but an alternative to each other. Similarly, asking for avoidance of contract stops a buyer to seek price reduction for the same. In other words, right to have the defects rendered and the right to avoid contract are not parallel remedies when buyer opt to claim for price reduction. Therefore the execution of the price reduction does not allow a buyer to seek these remedies simultaneously.

Strictly relying on CISG the buyer has independent remedy of price reduction especially in two cases. In first situation, the seller cannot be asked for damages for the exemption under Article 79 when force majeure or hardship interferes with his performance. In other situation, the buyer gets benefit of additional compensation where he claims so but between concluding time of contract and delivery of goods the prices fall down. Practically, the buyer can opt method of calculation whichever fits him best; both Article 45 (1) (b) and 74 or according to Article 50. However, he is restricted not to demand double compensation for same loss.

Price reduction in CISG and set-off in both CISG and SOGA give a chance to preserve the bargain between the parties which is the core objective (raison d'être) of any sale contract. The remedy of price reduction provides an opportunity towards out of court settlement of a dispute therefore it would strengthen the relationship between the parties for future business ties. Adding such remedy to a legal regime will hopefully supplement the transactional activities by raising the confidence of buying party to safeguard his loss amicably and legally being a matter of right and without, intervention of court, unnecessary delays and avoidance of the contract. 


\section{Conclusion}

Price reduction being a remedy on contractual breach is more likely to be found in continental European legal systems and less present in common law countries. Furthermore, it is argued that this remedy was originated from Roman era. It is quite useful for the buyer as an independent right coexisting with right to claim damages under Article 45 (1) (b) of CISG. The buyer has not to provide the reasonably defendable detail of loss he may receive as in case of claiming damages for choosing the remedy of price reduction.

The remedy of price reduction brings higher value of price for the buyer even if the prices go down after concluding the contract by enhancing the difference of price of defective goods and the desired goods as determine by price reduction formula. Therefore, it would be a better additional choice for commercial buyers if available with clear expression in sales law of Pakistan.

\section{References}

Agapiou, N. (2015). Buyer's remedies under the CISG and English sales law: a comparative analysis (Doctoral dissertation, University of Leicester).

Anselmo, Martinez Canellas (2005). The Scope of Article 44 CISG: Partial Exemption When the Buyer Does Not Communicate in Time the Lack of Conformity of the Goods in an International Sale. Journal of Law and Commerce, 25(1).

Beheshti, R. (2016). Price reduction versus damages: a battle without a winner. Uniform Law Review, 21(2-3), 216-237.

Bergsten, E. E., \& Miller, A. J. (1979). The remedy of Reduction of Price. American Journal of Comparative Law, 27, 255.

Cornelius, S. J. (2013). Banda v Van der Spuy 20134 SA 77 (SCA) Quantifying a claim with the actio quanti minoris. De Jure Law Journal, 46(3), 875.http://www.scielo.org.za/scielo.php?script=sci_arttext\&pid=S2225-71602013000300015

Demirel, G. (2019). Possible Legal Consequences of Trade Wars on the International Sale Contract Subject to the United Nations Convention on Contracts for the International Sale of Goods. Willamette Journal of International Law and Dispute Resolution, 26(1/2), 249-278.

Malik, M. E., \& Ahmed, N. (2018). Remedies for Breach of Contract: An Appraisal of the Contract Act, 1872 Of Pakistan. Journal of the Research Society of Pakistan, 55(2).

Flechtner, H. (2007). Article 79 of the United Nations Convention on Contracts for the International Sale of Goods (CISG) as Rorschach Test: The Homeward Trend and Exemption for Delivering NonConforming Goods. Pace International Law Review, 19, 29.

Fountoulakis, Christiana (2011). Remedies for Breach of Contract under the United Nations Convention on the International Sale of Goods. Era Forum, 12(1), 7-23.

Friedmann, Daniel (1995). The Performance Interest in Contract Damages. Law Quarterly Review, 111, $628,632$.

Gonzalez, Olga (1984). Remedies under the UN Convention for the International Sale of Goods. International Tax \& Business Law, 2, 79.

Han, Ki Moon (2016). A Study on Price Reduction under CISG and Issues. International Commerce \& Law Review, 69, 45-62.

Honnold, J. (2009). Uniform law for international sales under the 1980 United Nations Convention. Kluwer Law International BV.

Huber, P. (2007). CISG-The Structure of Remedies. Rabels Zeitschrift für ausländisches und internationales Privatrecht/The Rabel Journal of Comparative and International Private Law, (H. 1), 13-34.

Jansen, Sanne (2013). Price Reduction under the CISG: A $21^{\text {st }}$ Century Perspective. Journal of Law and Commerce, 32, 325.

Kalamees, P., \& Sein, K. (2015). Price Reduction in the System of Contractual Remedies. European Review of Private Law, 23(2), 263. 
Karachi Gas Co. Ltd. v Daewoo Cotton Mills Ltd. [reported as PLD 1975 SC 193]

Khalil (Pvt.) Limited v. M.V. Wales II [reported as 2012 CLD 276 (b) Sindh]

Lazerow, Herbert I (2019). Uniform Interpretation of CISG. The International Lawyer, 52(3), 369-391.

Magnus, Ulrich (2010). The Vienna Sales Convention (CISG) between Civil and Common Law-Best of all Worlds. Journal of Civil Law Studies, 3, 67.

Messrs Ahmed Abdul Gani, Merchants v Messrs Rahmania Trading Co., Merchants [reported as P L D 1958 Dacca 512]

Messrs Nawab Brothers Ltd v Project Director, Office of the Project Director, Special Projects, Planning and Development Department, Karachi (reported as 1981 CLC 638 Kar.)

Piche, Catherine (2002). The Convention on Contracts for the International Sale of Goods and the Uniform Commercial Code Remedies in Light of Remedial Principles Recognized under US Law: Are the Remedies of Granting Additional Time to the Defaulting Parties and of Reduction of Price Fair and Efficient Ones. North Carolina Journal of International Law and Commercial Regulation, 28, 519.

Piliounis, Peter A (2000). Remedies of Specific Performance, Price Reduction and Additional Time (Nachfrist) under the CISG: Are these Worthwhile Changes or Additions to English Sales Law. Pace International Law Review, 12, 1.

Raza, Hassan (2019). Liquidated Damages-Common Law versus Pakistani Law. LUMS Law Journal, 6, 49. https://sahsol.lums.edu.pk/sites/default/files/liquidated_damages_0.pdf

Scarf versus Jardine, (1882) 7 AC 345

Schwenzer, I. (2012). Conformity of the Goods-Physical Features on the Wane?. https://edoc.unibas.ch/21206/6/20120413143056_4f881c80d278bPDFA2.pdf

Schwenzer, Ingeborg (2017). Ethical Standards in CISG Contracts. Uniform Law Review, 22(1), 122-131.

Shin, Chang-Sop (2005). Declaration of Price Reduction under the CISG Article 50 Price Reduction Remedy. Journal of Law and Commerce, 25, 349.

Šobot, Sandra Fišer (2017). Calculation of Price Reduction in International Sale of Goods Contracts. LeXonomica, 9(2), 109-124.

$\begin{array}{lllll}\text { The Contract Act, } 1872 & \text { Pakistan https://www.ma- }\end{array}$ law.org.pk/pdflaw/Contract\%20Act,\%201872.pdf

The Sale of Goods Act, 1930 of Pakistan (SOGA). http://www.pljlawsite.com/Statuteview.asp?ID=5835

The United Nations Convention on Contracts for the International Sale of Goods, 1980 (CISG or Vienna Sales Convention). https://www.uncitral.org/pdf/english/texts/sales/cisg/V1056997-CISG-e-book.pdf

United Bank Limited v Messrs Aziz Tanneries (Pvt) Ltd. [reported as 2004 CLD 1715 Lah.]

Weinrib, Ernest J (2003). Punishment and Disgorgement as Contract Remedies. Chicago-Kent Law Review, 78, 55.

Zeller, Bruno, and Sarmad Ali (2017). Should Pakistan Adopt the Convention of Contracts for the International Sale of Goods. Victoria University Law \& Justice Journal, 7, 66. 